Mehmet Akif Ersoy Üniversitesi Fen Bilimleri Enstitüsü Dergisi 11(1): $34-37$ (2020)

The Journal of Graduate School of Natural and Applied Sciences of Mehmet Akif Ersoy University 11(1): $34-37$ (2020)

Araştırma Makalesi / Research Paper

\title{
Konya ve Aydın İllerinde Çilekte Enfeksiyon Oluşturan Bazı Önemli Virüsle- rin Belirlenmesi
}

\author{
Handan ÇULAL KILIÇ ${ }^{(D)}{ }^{*}$, Raziye YETiK ${ }^{(D)}$, Selda IŞIK (D) \\ ${ }^{1}$ Isparta Uygulamalı Bilimler Üniversitesi, Ziraat Fakültesi, Isparta \\ Geliş Tarihi (Received): 05.02.2020, Kabul Tarihi (Accepted): 07.04.2020 \\ $\square$ Sorumlu Yazar (Corresponding author*): handankilic@isparta.edu.tr \\ (C) +902462146282 且 +902462146269
}

ÖZ

Bu çalışma, 2017 üretim yılı Konya ve Aydın İlleri çilek üretim alanlarında yürütülmüştür. Survey alanlarında virüs belirtisi gösteren 92 yaprak örneği toplanmıştır. Toplanan örneklerde Strawberry latent ringspot virus (SLRSV) ve Strawberry mild yellow edge virus (SMYEV)' lerinin varlığını belirlemek amacıyla DAS-ELISA (Double Antibody Sandwich Enzyme Linked Immunosorbent Assay) yöntemi kullanılmıştır. DAS-ELISA testi sonucunda 92 örnekten 38 adedinin virüsler ile enfekteli olduğu tespit edilmiştir. Elde edilen sonuçlara göre; 4 örnekte SLRSV, 29 örnekte SMYEV, 5 örnekte de karışık enfeksiyon ortaya konulmuştur.

Anahtar Kelimeler: Çilek, virüs hastalıkları, DAS-ELISA

\section{Detection of Some Important Viruses Infecting in Konya and Aydın Provin- ces}

\begin{abstract}
This study was carried out in strawberry production areas in Konya and Aydın provinces in 2017. In the surveys; the total of 92 leaf samples were collected from strawberry plants with virus like symptoms. Collected samples were tested by DAS-ELISA (Double Antibody Sandwich Enzyme Linked Immunosorbent Assay) to determine the presence of Strawberry latent ringspot virus (SLRSV) and Strawberry mild yellow edge virus (SMYEV). According to DASELISA tests; It was determined that 38 samples out of 92 were infected with viruses. In this results; SLRSV in 4 samples and SMYEV in 29 samples were found. 5 samples were infected with two viruses.
\end{abstract}

Keywords: Strawberry, virus diseases, DAS-ELISA

\section{GíRiş}

Çilek (Fragaria $x$ ananassa Duch.), gülgiller (Rosaceae) familyası içinde yer alan bir bitkidir (Hancock ve ark., 2008). Üzümsü meyveler içerisinde yer almaktadır. Çilek meyvesi çiçek tablasının şekerli ve sulu bir besin maddesiyle dolmasından meydana gelir. Yediğimiz kısım yalancı meyvedir. Asıl meyve çileğin üzerindeki siyah birer nokta gibi duran küçük çekirdekleridir. Çok yıllık bir bitki olup C vitamini, askorbik asit ve selüloz bakımından zengin bir meyvedir. Çilek, taze olarak tüketildiği gibi, işlenmiş ve kuru olarak değerlendirilmektedir. (Sarıgül, 2013).

Çileğin anavatanının Kuzey ve Güney Amerika olarak belirtilmiştir (Çakaryıldırım, 2004). Dünya çilek üretiminin \% 38'i Çin'de gerçekleşmektedir. Bunu ABD, Mek- 
sika, Türkiye, İspanya, Mısır, Kore ve Polonya takip etmektedir (İkinci ve ark., 2017). Dünya çilek üretimi 2016 yılı itibari ile 8,1 milyon ton'dur (FAO, 2017).

Ülkemizde çilek üretimin büyük çoğunluğu Akdeniz, Marmara ve Ege bölgelerinde yoğunlaşmıştır (İkinci ve ark., 2007). İ bazında baktığımızda Mersin, Aydın, Bursa, Antalya ve Konya illerinde yoğun olarak üretim yapılmaktadır. Özellikle Konya son yıllarda organik çilek üretimi bakımından gelişme göstermiştir (Atasay ve Türemiş, 2008). Türkiye'de TÜIKK 2017 verilerine göre;154.308 da alanda 415 bin ton çilek üretimi yapılmıştır.

Aydın ilinde TÜİK 2018 verilerine göre; yıllık çilek üretim miktarı 61.273 ton iken Konya ilinde 37.572 ton'dur (TÜİK, 2018).

Çilek yetiştiriciliğinde bazı yanlış tarımsal uygulamalar, fungal, bakteriyel ve viral hastalıklar önemli ürün kayıplarına yol açmaktadır. Viral hastalıklara karşı kimyasal mücadelenin olmaması viral hastalıkların önemini daha da arttırmaktadır.

Çilek üretim alanlarında görülen önemli virüs hastalıkları; Strawberry mild yellow edge virus (SMYEV), Strawberry mottle virus (SMoV), Strawberry vein banding virus (SVBV), Strawberry latent ringspot virus (SLRSV), Arabis mosaic virus (ArMV) ve Tomato ring spot virus (TRSV) dür (Martin ve Tzanetakis 2006, Yeşilçöllü ve ark., 2011, Dara, 2015, El-Morsy ve ark., 2017).

Virüs hastalıklarını oluşturduğu belirtiler ve zarar şekli bitkinin türüne, virüsün ırkına ve çevre şartlarına göre değişiklik göstermektedir. Bu sebeple virüs hastalıkları için yeni mücadele programlarının geliştirebilmesi için öncelikle kültür bitkisinde bulunan virüslerin belirlenmesi gerekmektedir. Serolojik yöntemler ile kısa zamanda çok sayıda örnek testlenebilmekte ve bu yöntemler birçok virüsün teşhisinde kolaylıkla kullanılabilmektedir (Clark ve Adams, 1977).

Ülkemizde çilekte virüs hastalıklarının belirlenmesi ile ilgili sınırlı sayıda çalışma bulunmaktadır. Özellikte Konya ilinde çilek üretim alanlarındaki virüs hastalıklarının teşhisi ile ilgili bir çalışma mevcut değildir. Bu çaIışma Konya ilinde çilek alanlarında sözü edilen virüslerin tanılanması bakımından özgün değere sahiptir.

Çalışma da Aydın ve Konya ili çilek üretim alanlarında SMYEV ve SLRSV'nin varlığının ortaya konulması amaçlanmıştır Bu amaçla örneklerdeki virüslerin varlığının araştırılması için serolojik yöntemlerden DAS-ELISA kullanılmıştır.

\section{MATERYAL VE YÖNTEM}

Çalışmanın materyalini Aydın ve Konya ili çilek üretim alanlarından toplanan yaprak örnekleri oluşturmuştur. Surveyler 2017 yılı Temmuz-Ağustos aylarında yapılmıştır. Araziden toplam 92 yaprak örneği toplanmıştır. Surveyler sırasında yapraklarında bodurluğa, kloroz ve nekroza, kızarmış yapraklara sahip ve deformasyona uğrayan çilek bitkileri tercih edilmiştir.

Yaprak örnekleri ayrı polietilen torbalara konulduktan sonra içlerine gerekli bilgileri kapsayan etiketler yerleştirilmiştir. Buz kutuları içerisinde laboratuvara getirilen örnekler $-20{ }^{\circ} \mathrm{C}$ 'deki derin dondurucuda DAS-ELISA yapılana kadar saklanmıştır.

Örneklerin serolojik testlenmesinde SMYEV, SLRV'e spesifik ELISA kitleri kullanılmıştır. Kitler Bioreba (İsviçre) firmasından temin edilmiştir. Testleme çalışmalarında firmanın önerdiği şekilde DAS-ELISA yöntemi uygulanmıştır. Sırasıyla (Sharma ve ark., 2018);

- ELISA pleytinin çukurları kaplama tamponu ile kaplanarak $+4{ }^{\circ} \mathrm{C}$ 'de bir gece inkubasyona bırakılmış ve inkubasyonu takiben pleytler boşaltılıp yıkama tamponu ile 3 kez yıkanmıştır.

- Genel ekstraksiyon tampon çözeltisinde 1/10 oranında hazırlanmış olan ekstrakt her çukura 200'er $\mu \mathrm{l}$ konulmuş ve $+4{ }^{\circ} \mathrm{C}$ 'de bir gece inkubasyona bırakılmış, ertesi gün yıkama tamponu ile pleytler yıkanmıştır.

- Konjugat tamponu içerisinde sulandırılmış Alkaline phosphatase enzimi ile etiketli konjugattan her çukura $200 \mu$ lilave edilerek $37^{\circ} \mathrm{C}$ 'de inkubasyona bırakılmıştır. İnkubasyondan sonra tekrar tüm çukurlar yıkama tamponu ile yine aynı şekilde yıkanmıştır.

- Substrat tamponu (P-nitrophenly phosphate) ile taze olarak hazırlanan substrattan her bir çukura $200 \mu \mathrm{l}$ konularak oda sıcaklığında inkubasyona bırakılmış ve renk değişimi gözlenmiştir. Absorbans değeri 405 nm dalga boyundaki ELISA okuyucunda ölçülmüştür.

- Negatif kontrolün absorbans değerinin ortalamasının en az iki katı ve üzerinde absorbans değeri veren örnekler pozitif olarak kabul edilmiştir.

\section{BULGULAR VE TARTIŞMA}

Araştırmanın yürütüldüğü Aydın ve Konya ilinde yapılan surveylerde çilek yapraklarında deformasyon, nekrotik lekeler, gelişme geriliği, yaşlı yapraklarda kızarma, yapraklarda içe doğru kıvrılma ve sararma gibi belirtiler gözlemlenmiştir (Şekil 1, 2). 


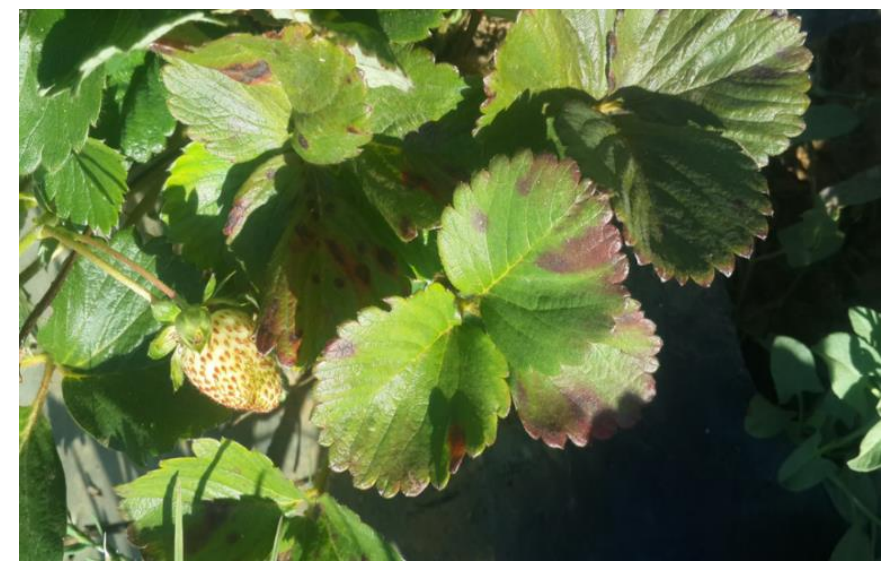

Şekil 1. Yaprak kenarlarında kızarıklık

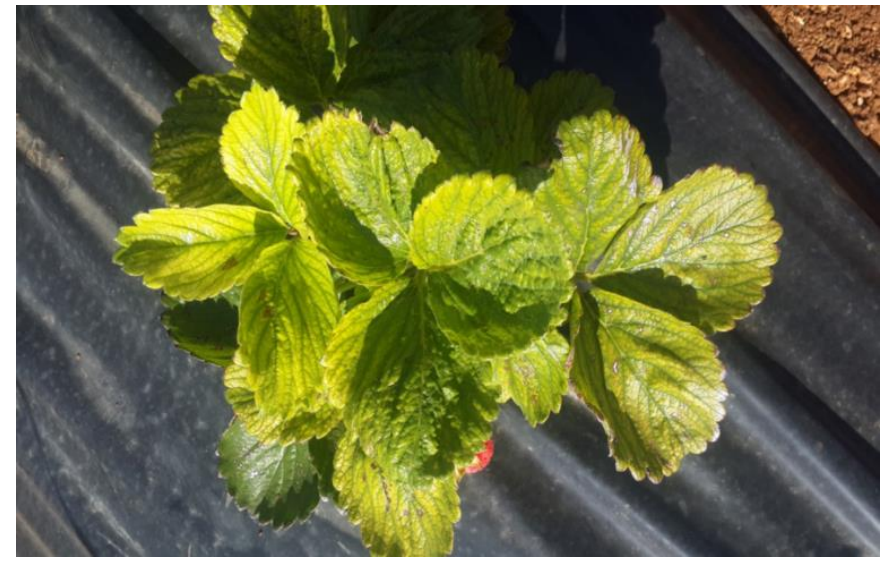

Şekil 2. Yapraklar üzerinde kabartı şeklinde belirtiler ve kloroz

Yapılan DAS-ELISA testi sonucunda toplanan 92 adet çilek örneğinin 38 adedinin virüslerle enfekteli olduğu tespit edilmiştir $(\% 41,30)$. ELISA testlerinin sonucunda; 4 örneğin (\%4.34) SLRV; 29 örneğin (\%31,52) SMYEV ile enfekteli olduğu belirlenmiştir. 5 örneğin $(\% 5,43)$ ise SLRV+SMYEV ile enfekteli olduğu belirlenmiştir (Tablo 1).

Tablo 1. Survey yapılan alanlar, toplanan örnek sayısı, enfekteli örnek sayısı

\begin{tabular}{|r|l|c|c|c|c|}
\hline \multirow{2}{*}{ SÜRVEY YAPILAN ALANLAR } & $\begin{array}{c}\text { TOPLANAN ÖRNEK } \\
\text { SAYISI }\end{array}$ & SLRSV & SMYEV & SLRSV+SMYEV \\
\hline \multirow{2}{*}{ AYDIN } & Didim-Akyeniköy & 13 & - & 1 & - \\
\cline { 2 - 6 } & Didim-Akköy & 17 & 1 & 2 & 1 \\
\hline \multirow{2}{*}{ KONYA } & Doğanhisar & 24 & 2 & 6 & 1 \\
\cline { 2 - 6 } & Hüyük & 38 & 1 & 20 & 3 \\
\hline \multicolumn{2}{r}{ TOPLAM } & $\mathbf{2}$ & $\mathbf{4}$ & $\mathbf{2 9}$ & $\mathbf{5}$ \\
\hline
\end{tabular}

Serolojik test sonuçlarına göre; SLRSV'nün enfeksiyon oranı \%8,33 ile en yüksek Konya-Doğanhisar yöresinde tespit edilmiştir. SMYEV'nün enfeksiyon oranı ise en yüksek \%52,63 ile Konya-Hüyük'te belirlenmiştir. Çalışmanın kapsamında örnek alınan bölgelerden Aydın-Akyeniköy'de testlenen virüslerden SLRSV bulunmamıştır.

Aydın ve Konya ili çilek üretim alanlarında virüslerin tanılanması ile ilgili yapılan çalışmalarda virüs semptomu gösteren yaprak örnekleri kullanılmıştır. Ancak bu semptomlu örneklerin negatif sonuç vermesi, farklı virüslerinde olabileceğini de göstermektedir. Nitekim farklı ülkelerde çilekte enfeksiyon oluşturan çok sayıda virüs hastalığı tespit edilmiştir (Ma ve ark., 2015, Handa ve Sharma, 2018, Sedlak ve ark., 2019).

Yeşilçöllü ve ark.(2011)' । İzmir ve Aydın çilek üretim alanlarında yaptıkları çalışma da SLRSV ve SMYEV etmenlerinin varlığını RT-PCR yöntemi kullanarak araştırmışlardır. RT-PCR sonucunda 221 örnekten 48 örnekte SMYEV tespit edilirken; örneklerin hiçbirinde SLRSV bulunamamıştır.

Yapılan bu çalışma ile çilekte SMYEV ve SLRV'nin varlığı Konya ilinde ilk kez ortaya konulmuştur. 


\section{SONUÇLAR}

SLRSV; aşılama, tohum, mekanik inokulasyon ve Xiphinema diversicaudatum nematodu ile taşınmaktadır. SMYEV ise aşı yoluyla ve Chaetosiphon fragaefolii afiti ile persistent tarzda taşınmaktadır (Dara, 2015). Bu çaIışma ile Konya ve Aydın illerindeki iki önemli virüsün varlığı ortaya konulmuş ve kimyasal mücadelesi bulunmayan bu patojenlere karşı alınabilecek önlemlerin önerilmesine olanak sağlanmıştır.

Çalışmamızda varlığı tespit edilen SLRSV nematod, SMYEV ise afitlerle taşındığı için öncelikle bu vektörler ile etkili bir şekilde mücadele edilmelidir. Ayrıca dayanıklı çeşitlerin ıslahı ve enfekteli bitkilerin eradikasyonu gibi işlemlerin bölgede yaygınlaştırılması gerekmektedir.

\section{KAYNAKLAR}

Atasay, A., Türemiş, N. (2008). Eğirdir (Isparta) koşullarında organik çilek yetiştiriciliğinin uygulanabilirliği üzerine bir araştırma. Çukurova Üniversitesi Fen Bilimleri Enstitüsü Dergisi 18(3): 72-81

Clark, M.F., Adams, A.N. (1977). Characteristics of the microplate method of enzyme-linked immunosorbent assay for the detection of plant viruses. Journal of General Virology 34: 475-483.

Çakaryıldırım, N. (2004). Çilek. Tarımsal Ekonomi Araştırma Enstitüsü-Bakış 7(12): 1-4.

Dara, S.K. (2015). Virus decline of strawberry in California and the role of insect vectors and associated viruses. Plant $\mathrm{He}$ alth Progress Doi:10.1094/Php-mr-15-0023.

El-Morsy, Sh.I., El-Sheikh, M.A., Abd El-Razik, R.A., Youssef, Sahar A., Shalaby, A.A. (2017). Molecular identification of
Strawberry Latent Ring Spot Virus (SLRSV) in Egypt. Journal of Basic and Environmental Sciences 4: 24-33.

FAO (2017). http://faostat.fao.org/site/567/. (22 Mayıs 2017).

Hancock, J.F., Sjulin, T.M., Lobos, G.A. (2008). Strawberries. In: Temperate Fruit Crop Breeding, Germplasm to Genomics Chapter: Hancock, J.F. (eds.), Kluwer Academic Publishers, Dordrecht, The Netherlands, 1-37.

Handa, A., Sharma, A. (2018). Incidence of major virus diseases of strawberry in north western Himalayan region of India. Journal of Pharmacognosy and Phytochemistry 7(5): 245-248

İkinci, A., Türemiş, N., Bolat, I. (2017). Çilek yetiştiriciliğinde ve çilek ıslahında güncel yaklaşımlar. Tarım Türk Dergisi 6064.

Ma, X., Cui, H., Bernardy, M., Tian L.,, Abbasi, P., Wang, A. (2015). Molecular characterization of a Strawberry mild yellow edge virus isolate from Canada. Canadian Journal of Plant Pathology, 37(3): 369-375.

Martin, R.R., Tzanetakis, I.E. (2006). Characterization and recent advances in detection of strawberry viruses. Plant Diseases 90:384-396.

Sarıgül, T. (2013). Düzce İli Çilek Üretim Alanlarında Görülen Fungal Hastalıkların Belirlenmesi. Ankara Üniversitesi, Fen Bilimleri Enstitüsü, Bitki Koruma Anabilim Dalı, Yüksek Lisans Tezi, 57.

Sedlák, J., Paprštein, F., Suchá, J. (2019): Influence of chemotherapy on development and production of virus free in vitro strawberry plants. Horticultural Science (Prague), 46: 53-56.

Sharma, A., Handa, A., Kapoor, S., Shylla, B. (2018). First report of Strawberry mild yellow edge virus in India. International Journal of Chemical Studies 6(3): 662-664

TÜIKK (2018). http://www.tuik.gov.tr/ (11 Mart 2018).

Yeşilļöllü, S., Gümüş, M., Paylan, I.C. (2011). Studies on the detection of viruses in strawberry growing areas in Aegean region. The Journal of Turkish Phytopathology 40(1-3): 1320. 